\title{
Checklist of butterfly fauna (Lepidoptera: Rhopalocera) of Sindh, Pakistan
}

\author{
Bhojoo Mal*, Nasreen Memon, Juma Khan Turk, Shakeel Ahmed \\ Memon, Mansoor Ali Shah and Nadir Ali Shah \\ Department of Zoology, University of Sindh, Jamshoro, Sindh, Pakistan \\ Corresponding author email: bhojumal@yahoo.com \\ Citation \\ Bhojoo Mal, Nasreen Memon, Juma Khan Turk, Shakeel Ahmed Memon, Mansoor Ali Shah and Nadir Ali Shah. \\ Checklist of butterfly fauna (Lepidoptera: Rhopalocera) of Sindh, Pakistan. Pure and Applied Biology. Vol. 3, Issue \\ 4, 2014, pp 199-203.
}

\begin{abstract} checklist of butterfly fauna of Sindh, Pakistan.

Keywords:Butterfly fauna, Checklist, Sindh, Pakistan. Introduction

Butterflies belong to order Lepidoptera. They are very delicate, beautiful and attractive due to their colourful scaly wings, considered as the symbol of beauty and grace [1]. They are diurnal (active at daytime) in habitats and easily recognized by their beautiful colour, shape and stylish flight that give pleasure to everyone [2]. Butterflies distributed every part of the world wherever the flowering plants found [3]. Butterflies are important pollinators for many varieties of plant because they fly over long distance, but at the same time, some of them are very serious pest of many crops and fruits. Caterpillars of most Pierid butterflies feed on various varieties of mustards (family Brassicaceae), legume and cabbage [4]. About 15,000-16000 species reported worldwide [5]. Out of these 400 species reported from the Pakistan [6, 7]. Entomologists have worked on different aspects such as biology, distribution and diversity of butterfly fauna from Pakistan. Doherty first time worked on the butterfly from Kashmir [8]. Swinhow explored buttery fauna from Karachi and its adjoining areas [9]. Marshal and de-Niceville reported the butterfly fauna of the Indian subcontinent [10]. Robert reported from different localities of the Pakistan [11]. Leslic and Evans reported the butterflies of Chitral [12]. Rhe-philipe
\end{abstract}

The present study was carried out from Sindh, Pakistan during 2012-2013. A total of 1,964 specimens of butterflies were collected from the different localities of Sindh, Pakistan. The identification was done through available literature. Among collected specimens, 67 species belonging to 41 genera of 16 subfamilies falling in 6 families were identified. Our result showed that Lycaenidae was the richest family; comprising 19 species followed by Pieridae comprising 18 species, Nymphalidae 11 species, Hesperiidae 11 species, Danaidae comprising 5 species and Papilionidae comprising 03 species were reported. The present study was first time attempt to make the and Puri worked on butterflies of India, Barma and some localities, which is now part of Pakistan [13, 14]. Evans studied the butterfly fauna of Baluchistan [15]. The butterfly fauna of the British- India region explored by many authors [16-19] some region were the part of Pakistan.

Previously, many scholars worked on the butterfly fauna from Pakistan. Very little research has been carried out from Sindh, Pakistan. Therefore, this study is an enormous source of information of butterfly fauna of Sindh, Pakistan. Furthermore, this checklist will be helpful for researchers to identify the species of butterfly.

\section{Materials and Methods}

\section{Study Site}

Sindh $\left(26.1000{ }^{0} \mathrm{~N}, 68.5000{ }^{0} \mathrm{E}\right)$ is located on the western side of South Asia (Fig. 1). Geographically it is the third largest province of Pakistan. It covers 140,914-km² area. Sindh bounded by Arabian ocean on south, Punjab on North, India on East and Balochistan on West. Sindh lies in a Subtropical region. Temperatures normally rise above $46^{\circ} \mathrm{C}\left(115^{\circ} \mathrm{F}\right)$ in Summer Season between May and August and the minimum average temperature about $2{ }^{\circ} \mathrm{C}\left(36^{\circ} \mathrm{F}\right)$ Winter season occurs during December and January in the northern and higher elevated regions [20]. 


\section{Collection and Preservation}

The specimens of Butterfly were collected with the help of insect net and hand picking during 2012-2013 from different localities of Sindh. Collection was made randomly about interval of 15 days from the different fields, crops, fruits and vegetables of Sindh such as Karachi, Hyderabad, Sukkur, Larkana, Mirpur Khas, Shaheed Benzirabad etc. Mostly researchers kill specimens using chloroform, but effect on the colouration of butterflies, make difficulty for identification. That is why specimens put in the jar and kept in the fridge for twenty-four hours. Then insect pin inserted in the thorax, stretched on the stretching board, kept in that position for 24 hours. Transfer to the insect boxes with Naphthalene balls for protection from the ants and other Entomophagous. Identification was done by literature available [21-24] keys followed [25, 26]. Identified species of butterflies were labeled properly.

Table 1. Superfamilies, families; number of subfamilies, genera, species and percentage of butterflies recorded in Sindh, Pakistan

\begin{tabular}{lllcccc}
\hline S.No & Superfamily & Families & $\begin{array}{l}\text { No. of } \\
\text { Subfamilies }\end{array}$ & $\begin{array}{l}\text { No. of } \\
\text { Genera }\end{array}$ & $\begin{array}{l}\text { No. of } \\
\text { Species }\end{array}$ & $\begin{array}{l}\text { Percentage } \\
\text { of Species }\end{array}$ \\
\hline $\mathbf{0 1}$ & Papilionoidea & Danaidae & 01 & 03 & 05 & $8 \%$ \\
& & Pieridae & 03 & 09 & 18 & $27 \%$ \\
& & Papilionidae & 01 & 02 & 03 & $5 \%$ \\
& & Nymphalidae & 04 & 07 & 11 & $16 \%$ \\
02 & Hesperioidea & Lycaenidae & 04 & 11 & 19 & $28 \%$ \\
\hline
\end{tabular}

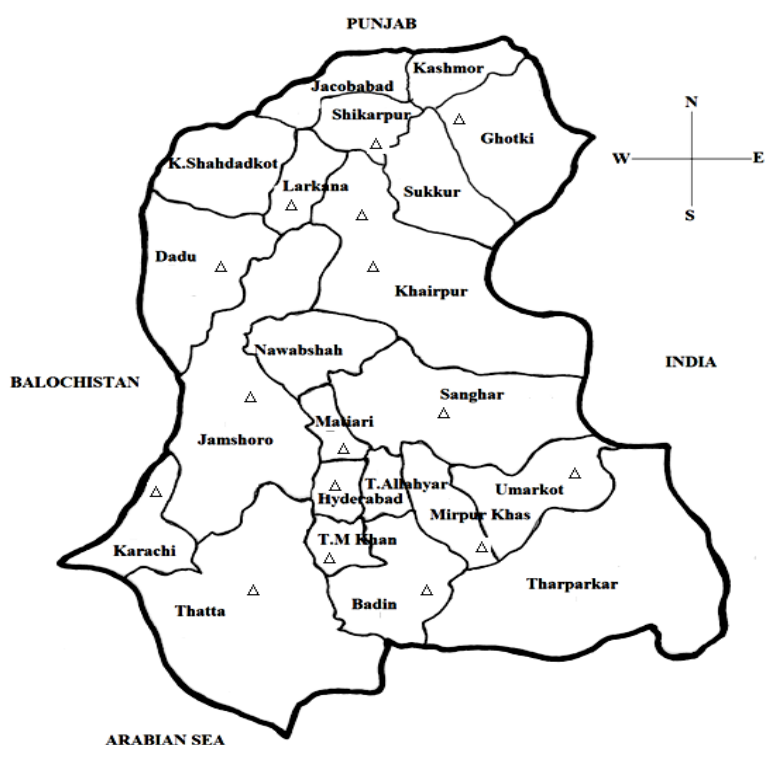

Fig 1. Map of Sindh, showing the sampled site.

\section{Results and Discussion}

During study period, 1,964 specimens of butterflies were collected from the different localities of Sindh, Pakistan during 2012-2013. Among specimens sixtyseven species of butterfly were identified.

\section{SUPERFAMILY: PAPILIONOIDEA (TRUE BUTTERFLIES)}

1.1.Family: Danaidae

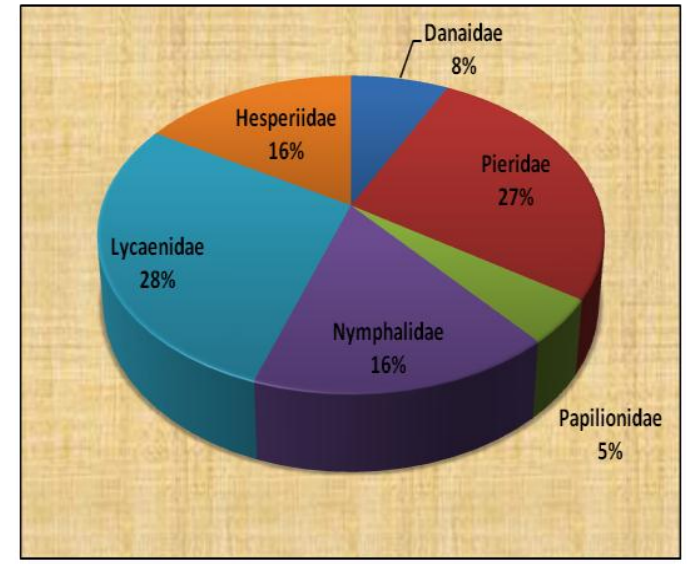

Fig 2. Family wise percentage of species recorded from Sindh, Pakistan.

\section{ORDER: LEPIDOPTERA}

Superorder: Rhopalocera

1. Superfamily: Papilionoidea (True Butterflies)

2. Superfamily: Hesperioidea (Skipper-Butterflies)

\subsubsection{Subfamily: Danainae}

Genus: Danaus

Danaus chrysippus Linnaeus, 1758 (Plain Tiger) 
Danaus plexippus Linnaeus, 1758 (Monarch Butterfly)

Danaus genutia Cramer, 1779 (Common Tiger)

Genus: Euploea

Euploea core Cramer, 1780 (Common Crown)

Genus: Tirumala

Tirumala limniace Cramer, 1775 (Blue Tiger)

1.2. Family: Pieridae

1.2.1. Subfamily: Coliaclinae

Genus: Colias

Colias croceus Geoffroy, 1785 (Dark Clouded Yellow)

Colias erate Esper, 1805 (Eastern pale clouded yellow)

\subsubsection{Subfamily: Coliadinae}

Genus: Catopsila

Catopsila crocale Fabricius, 1775 (Common

Emigrant)

Catopsilia florella Fabricius, 1775 (Common vagrant)

Catopsilia pomona Fabricius, 1775 (Lemon

Emigrant)

Catopsila pyranthe Linnaeus, 1758 (Mottled

Emigrant)

Genus: Colotis

Colotis amata Fabricius, 1775 (Small Salmon Arab)

Colotis danae Fabricius, 1775 (Crimson Tip)

Colotis etrida Boisduval, 1836 (Little Orange Tip)

Colotis fausta Olivier, 1804 (Large Salmon Arab)

Colotis protractus Butler, 1876 (Blue Spotted Arab)

Colotis vestalis Butler, 1876 (White Arab)

Genus: Eurema

Eurema hecabe Linnaeus, 1758 (Common Grass

Yellow)

Eurema laeta Boisduval, 1836 (Spotless Grass

Yellow)

Genus: Ixias

Ixias pyrene Linnaeus, 1764 (Yellow Orange Tip)

1.2.3. Subfamily: Pierinae

Genus: Appias

Appias libythea Fabricius, 1775 (Stripped Albatross)

Genus: Anapheis

Anaphies aurota Fabricius, 1793 (Pioneer)

Genus: Pieris

Pieris brassicae Linnaeus, 1758 (Large Cabbage White)

Pieris rapae Linnaeus, 1758 (Small Cabbage White)

Genus: Leptosia

Leptosia nina Fabricius, 1793 (Psyche)

1.3. Family: Papilionidae

1.3.1. Subfamily: Papilioninae

Genus: Papilio

Papilio demolus Linnaeus, 1758 (Lime Butterfly) Papilio polytes Linnaeus, 1758 (Common Mormon)

Genus: Pachilopta
Pachilopta aristolochiae Fabricius, 1775 (Common Rose)

1.4. Family: Nymphalidae

1.4.1. Subfamily: Acraeinae

Genus: Acraea

Acraea violae Fabricius, 1775 (Tawny Coster)

1.4.2. Subfamily: Morphinae

Genus: Ypthima

Ypthima asterope Klug, 1832 (Common Three-ring)

1.4.3. Subfamily: Nymphalinae

Genus: Junonia

Junonia almanac Linnaeus, 1758 (Peacock Pansy)

Junonia hierta Fabricius, 1798 (Yellow Pansy)

Junonia lemonias Linnaeus, 1758 (Lemon Pansy)

Junonia orithya Linnaeus, 1758 (Blue Pansy)

Genus: Hypolimnas

Hypolimnas bolina Linnaeus, 1758 (Great Eggfly)

Hypolimnas misippus Linnaeus, 1764 (Danaid Eggfly)

Genus: Vanessa

Vanessa cardui Linnaeus, 1758 (Painted Lady)

1.4.4. Subfamily: Satyrinae

Genus: Melanitis

Melanitis leda Linnaeus, 1758 (Common Evening Brown)

Genus: Phalantha

Phalantha phalantha Drury, 1773 (Common Leopard)

1.5. Family: Lycaenidae

1.5.1. Subfamily: Lycaeninae

Genus: Catochrysops

Catochrysops strabo Fabricius, 1793 (Forget-me-not)

Genus: Leptotes

Leptotes plinius Fabricius, 1793(Zebra Blue)

Genus: Tarucus

Tarucus balkanicus nigera Bethune-Baker, 1918 (Black Spotted Pierrot)

Tarucus extricates Butler, 1886 (Rounded Pierrot) Tarucus callinaria Butler, 1886 (Spotted Pierrot) Tarucus Theophrastus Fabricius, 1793 (Tiger Blue)

1.5.2. Subfamily: Miletinae

Genus: Azanus

Azanus jesos Guérin-Méneville, 1849 (African Babul Blue)

Azanus ubaldus Stoll, 1782 (Bright Babul Blue)

Azanus Uranus Butler, 1886 (Dull Babul Blue)

1.5.3. Subfamily: Polyommatinae

Genus: Chilades

Chilades Laius Cramer 1782 (Lime Blue)

Chiladespandava Horsfield, 1829 (Plain Cupid)

Chiladesparrhasius Fabricius, 1793 (Small Cupid)

Genus: Lampides

Lampides boeticus Linnaeus, 1767 (Pea Blue)

Genus: Zizeeria 
Zizeeria karsandra Moore, 1865 (Dark Grass Blue) Zizeeria knysa Trimen 1862 (African Grass Blue)

Genus: Zizula

Zizula hylax Fabricius 1775 (Tiny Grass Blue)

1.5.4. Subfamily: Theclinae

Genus: Apharitis

Apharitis acamas Klug 1834 (Tiny Silver Lime)

Genus: Spindasis

Spindasis elima Moore 1877 (Scarce Shot Silverline)

Genus: Virachola

Virachola Isocrates Fabricius 1793 (Common Guava Blue)

2. SUPERFAMILY: HESPERIOIDEA (Skipper Butterflies)

2.1. Family: Hesperiidae

2.1.1. Subfamily: Coeliadinae

Genus: Badamia

Badamia exclamationis Fabricius 1775 (Brown Awl)

Genus: Hasora

Hasora chromus Cramer 1782 (Common banded Awl)

2.1.2. Subfamily: Hesperiinae

Genus: Guttatus

Guttatus bevani Moore 1881 (Bevans Swift)

Genus: Gegenes

Gegenes nostrodamus Fabricius, 1793 (Dingy Swift)

Genus: Suastus

Suastus gremius Fabricius, 1798 (Indian Palm Bob)

Genus: Plebejus

Plebejus sephyrus Frivaldsky, 1835 (Balochi Jewel

Blue)

Pelopidas mathias Fabricius, 1798 (Small Branded

Swift)

2.1.3 Subfamily: Pyrginae

Genus: Gomalia

Gomalia elma Trimen, 1862 (African Marbled

Skipper)

\section{Genus: Spialia}

Spialia geron Watson, 1893 (Evanidus Sindh

Skipper)

Spialia galba Fabricius, 1793 (Indian Skipper)

Genus: Sarangesa

Sarangesa purendra Moore, 1882 (Spotted Small Flat)

\section{Discussion}

Butterfly fauna explored by many scholars from the different provinces of Pakistan. Ahsan and Iqbal surveyed butterfly fauna of Lahore from different localities [27]. Naz studied butterfly fauna of Buner Khyber Pakhtunkhwa in the period of 10 months [28]. Fitzherbert explained the diversity and the distribution of butterflies, 90 species recorded between Gilgit and Khunjerab at high altitude [29]. Some of them were highly distributed but other are less tolerant species present in colonies. Khan reported 20 species from Mirpur, 19 species from Bhimber and 16 species from Kotli. A total 450 specimens were collected; out of these specimens, 36 species of 25 genera belonging to 8 families were identified, he also reported the distribution and diversity of four species of genus Papiliofrom10 different sites of Rawalpindi and Islamabad [30]. Parveen explored the butterfly fauna from Kohat (Khyber Pakhtunkhwa), Pakistan, identified 21 species of 3 families namely Nymphalidae 33\%, Papilionidae 10\% and Pieridae 57\% [31].

Previously scholars work done on butterflies from the different localities of Pakistan, but Sindh province is mainly untouched regarding butterflies. The present study was the first time attempt to give checklist of butterfly fauna of Sindh, Pakistan. During studied period (2012-2013), 1,964 specimens were collected from the different localities of the Sindh; Sixty-seven species belonging to forty-one genera from sixteen subfamilies falling in six families. Lycaenidae was the richest family; comprising 19 species (28\%) followed by Pieridae comprising 18 species (27\%), Nymphalidae 11 species (16\%), Hesperiidae 11 species (16\%), Danaidae comprising 5 species (8\%) and Papilionidae comprising 03 species $(5 \%)$ were reported (Table. 1\& Fig. 2). Danaus chrysippus (Linnaeus, 1758) and Eurema hecabe (Linnaeus, 1758) were the most abundant among all recorded butterfly. The main objective of this study is to do the thorough survey of Sindh, as to record the species of the butterflies. To explore the new localities for occurrence of different species which were previously not surveyed. To establish the status of butterfly species, which are not included in previous record. This study will provide us the knowledge about the occurrence of different species of Butterflies of Sindh.

\section{References}

1. Rafi MA, Matin MA, Sheikh MK, Ashfaque, \& M (2000). Papilionid (swallowtails) butterflies of Pakistan. Gul Awan Printers, Islamabad, Pakistan2: 1-33.

2. Javed I (1978). Preliminary report of butterflies of district Rawalpindi and Islamabad. Biologia 24(2): 238-247.

3. Khan MR, Nasim M, Khan MR, \& Rafi MA (2004). Diversity of butterflies from district Muzaffarabad, Azad Kashmir. Pakistan Journal of Biological Sciences 7(3): 324-327.

4. Mal B, Memon N, Shah MA, \& Shah NA (2013). Re description and New Record of Small Arab Group of Genus Colitis (Lepidoptera: Pieridae) from Jamshoro, Sindh, Pakistan. Sindh Univ. Res. Jour. (Sci. Ser.) 45 (2): 357-364. 
5. Hassan SA (1994). Butterflies of Islamabad and Murree hills. Asian Study Group, Islamabad, Pakistan. 68p.

6. Khan MR, Rafi MA, Ilyas M, \& Safder M (2000). Distribution and diversity of Papilio spp. (Lepidoptera: Papilionid) Rawalpindi and Islamabad. Pakistan Journal of Scientific Research 52(1-2): 1-3.

7. Khan MR, Rafi MA, Munir M, Shoukat H, Baig MW, \& Khan MW (2007). Biodiversity of butterflies from districts Kotli, Mipur and Azad Kashmir. Pakistan Journal of Zoology 39(1): $27-$ 34.

8. Doherty W (1886). List of Butterflies taken in Kashmir. Journal of Asiatic Society of Bangladesh 55(3): 103-140.

9. Swinhow C (1887). On the Lepidoptera of Karachi and its neighborhood. Journal of the Bombay Natural History Society, Mumbai, India 2(1): 269-280.

10. Marshal GFL \& De-Niceville L (1890). The butterflies of India, Burma and Ceylon. Central Press Co., Calcutta, India. 327p.

11. Roberts TJ (2001). Butterflies of Pakistan. Oxford University Press, London and New York. $200 \mathrm{p}$

12. Leslic \& Evans WH (1903). The identification of Indian butterflies (Papilionidae, Pieridae). Journal of the Bombay Natural History Society, Mumbai, India.260p.

13. Rhe-philipe G (1917). The butterflies of Lahore. Journal of the Bombay Natural History Society, Mumbai, India 25(1): 136-142.

14. Puri DR (1931). Butterflies of Lahore. Thesis, Govt. College Lahore. 61p.

15. Evans WH1 (1932). The identification of Indian butterflies. Journal of the Bombay Natural History Society, Mumbai, India, 2: 1-672.

16. Bingham CT (1905). The fauna of British India including Ceylon and Burma. Butterflies, 1. Taylor and Francis Ltd., London, UK 15(1-2):1528.

17. Lefroy HM (1909). The Indian insect Life. Central Press Co., Calcutta, India. 786p.

18. Evans WH (1933). The butterflies of Balochistan. Journal of the Bombay Natural History Society, Mumbai, India 36 (1): 196-209.

19. Talbot G \& RRES (1932). The fauna of British India including Ceylon and Burma Butterflies Vol.I Taylor and Francis, LTD, Red Lion court, Fleet street London.591p.

20. Weiss, Anita M \& Mughal MAZ (2012). Pakistan". Louis Kotzé and Stephen Morse (eds), Berkshire Encyclopedia of Sustainability 9:236-240.
21. Bingham CT (1905). The fauna of British India including Ceylon and Burma. Butterflies, 1. Taylor and Francis Ltd., London, UK 15(1-2):1528.

22. Bingham CT (1907). Fauna of British India. Butterflies, 2, 34-36 Boisduval J.B. (1836) Anthocharis etrida Boisduval, 1836. Natural History Insect Specimen Genus Lepidoptera. $576 \mathrm{p}$.

23. Evans WH (1903). The identification of Indian butterflies (Papilionidae, Pieridae). Journal of the Bombay Natural History Society, Mumbai, India29: 230-260

24. Talbot G, FRES (1939). The fauna of British India including Ceylon and Burma Butterflies Vol.I Taylor and Francis, LTD, Red Lion court, Fleet street London. 599p

25. Abbas M, Rafi MA, Inayatullaha M \& Pavulaan $P$ (2002). Taxonomy and distribution of butterflies of the Skardu region, Pakistan. Taxonomic Report, the International Lepidoptera Survey (TILS), USA 3(9):1-9.

26. Munir A, Yasmin N, Rafi MA, Pavulaan H \& Wright D (2007). Bionomic studies of Papilio demoleus Linnaeus, the citrus butterfly (Lepidoptera: Papilionid) from lower Sindh, Pakistan. Taxonomic report of the International Lepidoptera survey 6(8): 1-11.

27. Ahsan M \& Iqbal J (1975). A contribution to the butterflies of Lahore with the addition of new records. Biologia 24(2): 238-247.

28. Naz F, Rafi MA, Inyatullah M, Khan MR \& Tuzov V (2001). The butterflies of the Buner district, North-West Frontier Province, Pakistan. In: Churkin, S. (Ed.), Helios collection of Lepidopterological articles. Oxford University Press, Oxford, UK 2: 123-224.

29. Fitzherbert E, Gardner T, Davenport TRB \& Caro T (2006). Butterfly species richness and abundance in the Katavi ecosystem of western Tanzania. African Journal of Ecology 44(3): 53362.

30. Khan MR, Rafi MA, Munir M, Shoukat H, Baig MW, \& Khan MW 2007. Biodiversity of butterflies from districts Kotli, Mipur and Azad Kashmir. Pakistan Journal of Zoology 39(1): 2734.

31. Perveen F \& Ahmad A (2012). Check list of butterfly fauna of Kohat, Khyber Pakhtunkhwa, Pakistan Arthropods 1(3): 112-117. 